\title{
Problematika Kontrak Karya Dalam Hukum Perjanjian Di Indonesia
}

\author{
Lukman Santoso \\ Muh Fauzi Arifin \\ IAIN Ponorogo \\ lukmansantoso4@gmail.com \\ muh.fauziarifin22@yahoo.com
}

\begin{abstract}
This article aims to describe the position of contract work in the legal agreements relating to mining activities in Indonesia. Based on the study of this article, formulated conclusion a few things, first, Indonesia is a country that has abundant natural resources, one of which in mining. In terms of exploration and exploitation of mining, Indonesia still apply cooperation with foreign parties. This provision is stipulated in the law of investment. This cooperation came to be known by the work contract. Second, the work contract is born started when the Indonesian government in April 1967 signed the first contract with Freeport McMoRan mining of the United States. The contract, known as first-generation contract of work. In the contract in principle the right of state control provides the authority to organize, manage and supervise the management or operation of the mine. However, it turns out in praktinya, the management of foreign and precisely controlled by the central government as powerless and not exercise its authority to the fullest.
\end{abstract} Keywords: work contract, agreement, mining.

Abstract: Artikel ini membahas tentang kontrak karya pekerjaan tambang di
Indonesia. Hasil penelitian dapat disimpulkan bahwa, pertama, Indonesia
adalah negara yang memiliki banyak sumber daya alam, termasuk
pertambangan. Dalam proses eklorasi dan ekploitasi pertambangan,
Indonesia bekerjasama dengan perusahan asing. Bentuk kerjasama ini,
diatur dalam hukum investasi yang dikenal dengan istilah kontrak karya.
Kedua, kontrak karya pertama kali diterapkan sejak April 1967 antara
pemerintah dengan perusahaan pertambangan asal Amerika serikat, Freeport
McMoRan. Dalam kontra tersebut, pemerintah daerah diberi kewenangan
untuk mengorganisasi, mengelola dan mengawasi manajemen dan
operasional pertambangan. Akan tetapi dalam praktiknya, pemerintah pusat
memegang kendali penuh dalam operasional dan manajemen pertambangan. Kata Kunci: kontrak karya, persetujuan, pertambangan 


\section{Latar Belakang}

Indonesia merupakan negara yang kaya akan Sumber daya alam (SDA) termasuk salah satunya adalah sektor pertambangan seperti emas, perak, tembaga, minyak, gas bumi, batu bara dan lain-lain. (Abrar, 2004: 18). Pengaturantentang SDAdiatur dalam UU No.5 Tahun 1960 Tentang Peraturan Dasar Pokok-Pokok Agraria, hal ini dapat dilihat dalam Pasal 1 UUPA yang menyatakan bahwa seluruh aset bumi, air dan ruang angkasa, termasuk kekayaan alam yang terkandung didalamnya dalam wilayah Republik Indonesia sebagai karunia Tuhan Yang Maha Esa adalah bumi, air dan ruang angkasa Bangsa Indonesia dan merupakan kekayaan nasional. (Harsono, 1994: 479).

Dengan kata lain, pertambangan tersebut dikuasai oleh negara. Hak Penguasaan Negara berisi wewenang untuk mengatur, mengurus dan mengawasi pengelolaan atau pengusahaan pertambangan, serta berisi kewajiban untuk mempergunakan sebesar-besarnya untuk kemakmuran rakyat. Penguasaan oleh negara diselenggarakan oleh pemerintah.

Dalam pengelolaan pertambangan pemerintah memerlukan modal yang sangat besar, peralatan yang canggih, tenaga ahli dan terdapat pula resiko yang tinggi. Akan tetapi untuk melakukan semua itu, Pemerintah Indonesia masih mengalami keterbatasan baik dari fasilitas maupun dana untuk kegiatan eksplorasi dan ekploitasi, sehingga diperlukan adanya kerjasama dengan berbagai pihak. Dimana secara rinci diatur dalam undang-undang penanaman modal, baik penanaman modal dalam negeri (PMDN) maupun penanaman modal asing (PMA). Selain itu teknis pelaksanaan pengusahaan pertambangan yang melibatkan pemodal asing diatur tersendiri dalam beberapa peraturan Menteri Energi Sumber Daya Mineral. (Awaliyah, 2016: 122). Kerjasama yang dimaksud antara pemerintah dan investor dalam menanamkan modalnya di bidang pertambangan berupa Kontrak Karya. Kontrak Karya sendiri merupakan perjanjian antara pemerintah dengan pengusaha pertambangan yang menjadi dasar hukum bagi pihak pengusaha untuk melakukan kegiatan-kegiatan pertambangan di Indonesia.

Berkaitan dengan kegiatan pertambangan selain mendasarkan pada UUPA juga menggunakan UU terkait dengan pertambangan. Undangundang pertambangan pertama kali adalah UU No.11 Tahun 1967 Tentang Ketentuan-Ketentuan Pokok Pertambangan. Setelah 42 tahun digunakan, UU tersebut diganti dengan UU No.4 Tahun 2009 Tentang Pertambangan Mineral dan Batubara. Sehingga sistem pengelolaan pertambangan di Indonesia yang berlaku saat ini yaitu UU No. 4 Tahun 2009 tentang Pertambangan Mineral dan Batubara (untuk selanjutnya disebut Undang-undang Minerba). (Toruan, 2016: 257). 
Problematika Kontrak Karya Dalam Hukum Perjanjian Di Indonesia

\section{Konsepsi Hukum Kontrak Karya}

Kontrak (contract, contracten) disebut juga perjanjian. Namun menurut Subekti, pengertian kontrak lebih sempit dari perjanjian karena kontrak mensyaratkan bentuknya selalu tertulis, sedangkan perjanjian bentuknya selain tertulis dapat dilakukan secara lisan. Oleh karena itu, hukum kontrak merupakan spesies dari hukum perjanjian. (Abrar, 2004: 1820). Sedangkan kontrak karya merupakan kontrak yang dikenal di dalam pertambangan umum. Istilah kontrak karya merupakan terjemahan dari bahasa Inggris ,yaitu kata work of contract atau dapat diartikan bahwa kerja sama modal asing dalam bentuk kontrak karya yang terjadi apabila penanaman modal asing membentuk satu badan hukum Indonesia dan badan hukum ini mengadakan kerjasama dengan satu badan hukum yang mempergunakan modal nasional. (Salim HS, 2003: 63).

Sementara, menurut Suharyati Hartono bahwa kontrak karya adalah kontrak antara Pemerintah Republik Indonesia dengan Perusahaan berbadan hukum Indonesia, untuk melaksanakan usaha pertambangan bahan galian. Sedangkan menurut Nanang Sudrajat, kontrak Karya adalah legalitas pengusahaan bahan galian yang diperuntukkan bagi investor asing, melalui fasilitas Penanaman Modal Asing (PMA). (Sudrajat, 2013: 67). Dalam pasal 10 UU No. 11 Tahun 1967 tentang Ketentuan-ketentuan Pokok Pertambangan Umum, istilah yang lazim digunakan adalah perjanjian karya. Dalam hukum Australia, istilah yang digunakan adalah indenture, franchise agreement, state agreement atau government agreement. (Salim, 2005: 127).

Sedangkan dalam Pasal 1 Keputusan Menteri Pertambangan dan Energi Nomor 1409.K/201/M.PE/1996 tentang Tata Cara Pengajuan Pemprosesan Pemberian Kuasa Pertambangan, Izin Prinsip, Kontrak Karya dan Perjanjian Karya Pengusahaan Pertambangan Batu Bara, pengertian Kontrak Karya (KK) adalah suatu perjanjian antara Pemerintah Republik Indonesia dengan perusahaan swasta asing atau patungan antara asing dengan nasional (dalam rangka PMA) untuk pengusahaan mineral, (Trihastuti, 2013: 50). dengan berpedoman kepada Undang-undang No. 1 Tahun 1967 tentang Penanaman Modal Asing serta Undang-undang No. 11 Tahun 1967 tentang Ketentuan-ketentuan Pokok Pertambangan Umum, yang secara teknis diatur dalam Pasal 1 Keputusan Menteri Pertambangan dan Energi No. 1409.K/201/M.PE/1996 tentang Tata Cara Pengajuan Pemprosesan Pemberian Kuasa Pertambangan, Izin Prinsip, Kontrak Karya dan Perjanjian Karya Pengusahaan Pertambangan Batu Bara.

Dalam definisi ini, dikonstruksikan sebagai sebuah perjanjian. Subjek perjanjian adalah Pemerintah Indonesia dengan perusahaan swasta asing atau joint venture antara perusahaan asing dan perusahaan nasional. Objeknya 
adalah pengusahaan mineral. Pedoman yang digunakan dalam implementasi kontrak karya adalah Undang-undang No. 1 Tahun 1967 tentang Penanaman Modal Asing serta Undang-undang No. 11 Tahun 1967 tentang Ketentuanketentuan Pokok Pertambangan Umum. (Soelistijo, 2011: 79).

Definisi lain dari kontrak karya, dapat dibaca dalam Pasal 1 angka 1 Keputusan Menteri Energi dan Sumber Daya Mineral 1614 No. 2004 tentang Pedoman Pemprosesan Permohonan Kontrak Karya dan Perjanjian Pengusahaan Pertambangan Batu Bara dalam Rangka Penanaman Modal Asing. Dalam ketentuan tersebut Kontrak Karya (KK) adalah perjanjian antara Pemerintah Indonesia dengan pengusahaan berbadan hukum Indonesia dalam rangka penanaman modal asing untuk melaksanakan usaha pertambangan bahan galian, tidak termasuk minyak bumi, gas alam, panas bumi, radio aktif dan batu bara. berikut:

Sedangkan Ismail Suny mengartikan kontrak karya adalah, sebagai

kerja sama modal asing dalam bentuk kontrak karya (contract of work) terjadi apabila penanaman modal asing membentuk satu badan hukum Indonesia dan badan hukum ini mengadakan kerja sama dengan satu badan hukum yang mempergunakan modal nasional. (Salim, 2005: 128). Pandangan tersebut dapat dikatakan bahwa badan hukum asing yang bergerak dalam bidang kontrak karya harus melakukan kerja sama dengan badan hukum Indonesia yang menggunakan modal nasional. Namun, di dalam peraturan perundang-undangan tidak mengharuskan kerja sama dengan badan hukum Indonesia dalam pelaksanaan kontrak karya. Pertanyaannya sekarang bagaimana dengan kontrak karya yang seluruh modalnya dari pihak asing, seperti halnya PT. Freeport Indonesia. Sumber pembiayaan perusahaan ini $100 \%$ dari pihak asing dan perusahaan ini tidak bekerja sama dengan modal domestik.

Dengan demikian, definisi kontrak karya di atas perlu dilengkapi dan disempurnakan sehingga yang dimaksud dengan kontrak karya adalah suatu perjanjian yang dibuat antara Pemerintah Indonesia dengan kontrakror asing semata-mata dan/atau merupakan patungan antara badan hukum domestik untuk melakukan kegiatan eksplorasi maupun eksploitasi dalam bidang pertambangan umum, sesuai dengan jangka waktu yang disepakati oleh kedua belah pihak. (Salim, 2005, hal. 129). Dengan demikian, dapat ditentukan unsur-unsur yang melekat dalam kontrak karya, (Salim, 2005: 130), yaitu:

1. Adanya kontraktual, yaitu perjanjian yang dibuat oleh para pihak,

2. Adanya subjek hukum, yaitu Pemerintah Indonesia/pemerintah daerah (provinsi/kabupaten/kota) dengan kontraktor asing semata-mata dan/atau golongan antara pihak asing dengan pihak Indonesia,

3. Adanya objek, yaitu eksplorasi dan eksploitasi, 
4. Dalam bidang pertambangan umum, dan

5. Adanya jangka waktu di dalam kontrak.

Dengan adanya Keputusan Menteri Energi dan Sumber Daya Mineral 1614 No. 2004 tentang Pedoman Pemprosesan Permohonan Kontrak Karya dan Perjanjian Pengusahaan Pertambangan Batu Bara dalam Rangka Penanaman Modal Asing, maka pemerintah daerah, tidak lagi menjadi salah satu pihak dalam kontrak karya, sedangkan para pihaknya adalah Pemerintah Indonesia, yang diwakili oleh Menteri Energi dan Sumber Daya Mineral dengan badan hukum Indonesia. Sementara itu, kedudukan gubernur dan bupati/walikota sebagai salah satu pihak dalam kontrak karya. Jangka waktu berlakunya kontrak karya tergantung kepada jenis kegiatan yang dilakukan oleh perusahaan pertambangan. Jangka waktu berlakunya kegiatan eksploitasi adalah tiga puluh tahun. Jangka waktu itu juga dapat diperpanjang.

\section{Perkembangan Kontrak Karya di Indonesia}

Sistem kontrak dalam dunia pertambangan Indonesia telah dikenal sejak masa penjajahan Hindia Belanda, khususnya ketika mineral dan logam mulai menjadi komoditas yang menggiurkan. Melalui Indische Mijnwet 1899, Hindia Belanda mendeklarasikan penguasaan mereka atas mineral dan logam di perut bumi nusantara. Sejak saat itu, perbaikan kebijakan dilakukan, antara lain tahun 1910 dan 1918, juga dilengkapi dengan Mijnordonnantie (Ordonansi Pertambangan) pada tahun 1906. Perbaikan pada 1910 menambahkan pula Pasal 5a Indische Mijnwet, yang menjadi dasar bagi perjanjian yang sering disebut "5a contract". (Salim, 2005: 131). berikut:

Inti ketentuan Pasal $5 a$ Indische Mijnwet (IMW) adalah sebagai

1. Pemerintah Hindia Belanda mempunyai kewenangan untuk melakukan penyelidikan dan eksploitasi.

2. Penyelidikan dan eksploitasi itu dapat dilakukan sendiri dan mengadakan kontrak dengan perusahaan minyak dalam bentuk kontrak 5a atau lazim disebut dengan sistem konsesi. Sistem konsesi merupakan sistem dimana dalam pengelolaan pertambangan umum kepada perusahaan pertambangan tidak hanya diberikan kuasa pertambangan, tetapi diberikan hak menguasai hak atas tanah. Jadi, hak yang dimiliki oleh perusahaan pertambangan adalah kuasa pertambangan dan hak atas tanah.

Pada awal kemerdekaan Indonesia hingga akhir kekuasaan Orde Lama, sistem kontrak pertambangan tidak berkembang. Bahkan pemerintah Soekarno mengeluarkan kebijakan nasionalisasi modal asing sehingga membatalkan semua kontrak pertambangan yang pernah ada. Pada masa 
pemerintahan Soeharto, kontrak karya di bidang pertambangan umum mengalami perkembangan yang cukup signifikan. Investasi di bidang pertambangan dimulai sejak diundangkannya Undang-undang No. 1 Tahun 1967 tentang Penanaman Modal Asing dan Undang-undang No. 11 Tahun 1967 tentang Ketentuan-ketentuan Pokok Pertambangan.

Empat bulan setelah Undang-undang No. 1 Tahun 1967 tentang Penanaman Modal Asing yang diundangkan bulan Januari 1967, pemerintah pada bulan April menandatangani kontrak pertambangan pertama dengan Freeport McMoran dari Amerika. Kontrak tersebut dikenal dengan sebutan kontrak karya generasi I. Akibatnya warna Undang-undang No. 11 Tahun 1967 tentang Ketentuan-ketentuan Pokok Pertambangan sangat kental dipengaruhi oleh kepentingan investor asing. Pasal 8 Undang-undang No. 1 Tahun 1967 tentang Penanaman Modal Asing menyatakan dengan eksplisit bahwa Penanaman modal asing di bidang pertambangan didasarkan atas suatu kerja sama dengan pemerintah atas dasar kontrak karya atau bentuk lain sesuai dengan peraturan perundang-undangan yang berlaku.

Sedangkan dalam Pasal 10 Undang-undang No. 11 Tahun 1967 tentang Ketentuan-ketentuan Pokok Pertambangan disebut dengan eksplisit bahwa Menteri dapat menunjuk pihak lain sebagai kontraktor untuk pekerjaan yang belum mampu dikerjakan sendiri. Pemerintah mengawasi pekerjaan tersebut sedangkan perjanjiannya harus disetujui dahulu oleh pemerintah dengan berkonsultasi dengan DPR.

Model awal kontrak karya bukanlah konsep yang dirancang Pemerintah Indonesia, melainkan hasil rancangan PT. Freeport Indonesia. (Sangaji, 2002, hal. 76). Awalnya Menteri Pertambangan Indonesia menawarkan kepada Freeport konsep "Bagi Hasil" berdasarkan petunjuk pelaksanaan kontrak perminyakan asing yang disiapkan pada waktu pemerintahan Soekarno. Freeport menyatakan kontrak seperti itu hanya menarik untuk perminyakan yang dapat menghasilkan dengan cepat, tetapi tidak untuk pertambangan tembaga yang memerlukan investasi besar dan waktu lama untuk sampai pada tahap produksi. Ahli hukum, Freeport Bob Duke, menyiapkan sebuah dokumen yang didasarkan pada model "Kontrak karya" yang pernah digunakan Indonesia sebelum diberlakukan "kontrak bagi hasil." (Sangaji, 2002: 133).

Secara singkat kontrak karya mengambil jalan tengah antara model konsesi pada zaman kolonial Belanda di mana kontraktor asing mendapat hak penuh terhadap mineral dan tanah, dengan model kontrak bagi hasil di mana negara tuan rumah langsung mendapatkan hak atas peralatan dan prasarana dan dalam waktu singkat seluruh operasi menjadi milik negara.

Sejak Tahun 1967, kontrak karya yang dikenal pengusaha asing sebagai contract of work mengalami perubahan. Setiap perubahan dijadikan dasar sebutan bagi generasi kontrak. Oleh karena itu, kita mengenal kontrak 
karya generasi I hingga generasi VII. Pada dasarnya, perkembangan KK di Indonesia sejak generasi I-KK sampai dengan generasi VII-KK dapat dilihat dalam pokok- pokok perkembangan tonggak perubahan mendasar sebagai berikut: pada generasi I-KK yang bersifat window shopping sehingga isi KK sangat longgar bagi perusahaan dengan adanya tax holiday. Pada generasi IIKK mulai adanya divestasi saham perusahaan terutama perusahaan nasional dalam PMA, dan mulai dihilangkannya tax holiday. Pada generasi III-KK mulai diizinkannya joint venture. generasi IV-KK adanya keringanan perpajakan, khususnya pajak badan, di samping adanya percepatan dalam depresiasi/amortisasi.

Generasi V-KK adanya kelonggaran dalam divestasi atau PMA dapat menanamkan modalnya 100\%, sesuai dengan PP No. 20 Tahun 1994 dan berlanjut pada generasi VI-KK dan VII-KK. Sejak generasi V-KK mulai dikembangkan program frontier development/pengembangan wilayah termasuk community development dan pengembangan sektor hilir (smelter) untuk meningkatkan perolehan nilai tambah di dalam negeri. (Soelistijo, 2011: 81).

Tujuh bulan setelah diundangkan Pasal 10 Undang-undang No. 11 Tahun 1967 tentang Ketentuan-ketentuan Pokok Pertambangan tepatnya bulan Juli 1968, pemerintah menandatangani KK generasi II dengan INCO. Kontrak Karya generasi II ini didasarkan pada Instruksi Presiden Nomor 18 Tahun 1968 tentang Penetapan Kelonggaran-kelonggaran Perpajakan untuk Penanaman Modal Asing di Bidang Pertambangan Umum. Oleh karena itu, INCO dan 27 perusahaan kontraktor lainnya mendapatkan kemudahan perpajakan pada awal kegiatan penambangan mereka. Dengan demikian, dapat dikatakann bahwa ditandatanganinya kontrak karya dengan PT. Freeport Indonesia sampai dengan saat ini. Akan tetapi pada saat kontak ditandatangani, nilai mineral (mineral value) masih merupakan sesuatu yang belum pasti. Keadaan seperti itu tentu saja merugikan pihak Indonesia, karena ternyata dalam Kontrak Karya tidak terdapat klausul yang mengatur adanya kemungkinan di temukannya bijih yang sangat banyak didalam tambang. (Wiriosudarmo, 1995: 7).

\section{Problematika Kontrak Karya dalam Hukum Indonesia}

Kontrak Karya terjadi apabila adanya kesepakatan yang dituangkan dalam bentuk suatu perjanjian tertulis antara Pemerintah Indonesia dengan kontraktor asing semata-mata dan/atau merupakan patungan antara badan hukum asing dengan badan hukum domestik untuk melakukan kegiatan eksplorasi maupun eksploitasi di bidang pertambangan umum dalam jangka waktu tertentu. Subekti mengatakan bahwa Pasal 1320 Hukum Perjanjian KUHPdt ini menganut asas konsensualitas, artinya untuk 
melahirkan perjanjian cukup dengan sepakat saja dan perjanjian itu sudah dilahirkan pada saat atau detik tercapainya konsensus tersebut. (Subekti, 1995: 3). Penyelesaian sengketa dalam bidang pertambangan umum lebih sering dilakukan dalam bentuk konsiliasi dan arbitrase. Kegiatan usaha pertambangan merupakan kegiatan yang syarat dengan investasi. (Awaliyah, 2016: 112). Oleh karena itu, peraturan perundang-undangan yang mengatur tentang Kontrak Karya dapat dilihat dan dibaca pada berbagai peraturan perundang-undangan berikut ini: (Awaliyah, 2016: 134).

1. UU No. 1 Tahun 1967 tentang Penanaman Modal Asing Jo UU No. 11 Tahun 1970 tentang Perubahan dan Tambahan UU No. 1 Tahun 1967 tentang Penanaman Modal Asing. Ketentuan-ketentuan yang berkaitan dengan Kontrak Karya terdapat dalam Pasal 8 Undangundang No. 1 Tahun 1967 tentang Penanaman Modal Asing, yang berbunyi sebagai berikut:

a. Penanaman modal asing di bidang pertambangan didasarkan pada suatu kerja sama dengan pemerintah atas dasar Kontrak Karya atau bentuk lain sesuai dengan peraturan perundang-undangan yang berlaku.

b. Sistem kerja sama atas dasar Kontrak Karya atau dalam bentuk lain dapat dilaksanakan dalam bidang-bidang usaha lain yang akan ditentukan oleh pemerintah.

2. UU No. 6 Tahun 1968 tentang Penanaman Modal Dalam Negeri Jo UU No. 12 Tahun 1970 tentang Perubahan dan Tambahan UU No. 6 Tahun 1968 tentang Penanaman Modal Dalam Negeri.

3. Pasal 10 UU No. 11 Tahun 1967 tentang Ketentuan-ketentuan Pokok Pertambangan, Ada tiga hal yang diatur dalam Pasal 10 Undangundang No. 11 Tahun 1967 tentang Ketentuan-ketentuan Pokok Pertambangan, diantaranya:

a. Pemerintah/menteri dapat menunjuk kontraktor untuk melaksanakan pekerjaan yang berkaitan dengan eksplorasi maupun eksploitasi,

b. Perjanjiannya dituangkan dalam bentuk Kontrak karya, dan

c. Momentum perjanjiannya setelah disahkan oleh pemerintah.

4. UU No. 4 Tahun 2009 Tentang Pertambangan Mineral dan Batubara Undang-undang pertambangan yang pernah berlaku di Indonesia ada 2, pertama UU No. 11 Tahun 1961 Tentang Ketentuanketentuan Pokok Pertambangan dan UU No. 4 Tahun 2009 Tentang Pertambangan Mineral dan Batu Bara. UU yang pertama berlaku sangat lama, yaitu mulai tahun 1967 sampai dengan 2009. Setelah 32 tahun diberlakukan perlu adanya penyesuaian-penyesuaian terhadap kondisi nyata dilapangan. Hal ini berkaitan dengan keberadaan Indonesia yang sangat kaya dengan sumber daya alam sehingga 
banyak investor yang ingin menanamkan modalnya di Indonesia. Sementara itu pelaksanaan kontrak karya yang telah berlaku selama ini dirasa sangat tidak menguntungkan masyarakat Indonesia sebagai pemilik lahan. Oleh karena itu perlu dilakukan perubahan-perubahan dalam UU pertambangan yang baru yakni UU No. 4 Tahun 2009 yang memuat $26 \mathrm{Bab}$ dan 175 pasal.

5. UU No. 25 Tahun 2007 Tentang Penanaman Modal

Salah satu sumber daya yang sangat penting dalam pembangunan adalah modal yang digunakan dalam berbagai pengadaan dan pembiayaan berbagai kegiatan usaha. Pada awalnya upaya untuk menarik modal dilakukan dengan menggunakan berbagai cara, misalnya dengan kemudahan perijinan, keringanan pajak dan insentif. Penanam modal berasal dari dalam negeri dan luar negeri yang pengaturannya diatur melalui undang-undang. Undang-undang No. 25 Tahun 2007 Tentang Penanaman Modal yang dibagi dalam XVI bab dan 42 Pasal. (Ilmar, 2004, hal. 86-87).

6. Peraturan Pemerintah No. 23 Tahun 2010 Tentang Pelaksanaan Kegiatan Usaha Pertambangan Mineral dan Batubara

Peraturan pelaksana dari UU pertambangan tahun 2009 ini adalah Peraturan Pemerintah No. 23 Tahun 2010 Tentang Pelaksanaan Kegiatan Usaha Pertambangan Mineral dan Batubara. Beberapa hal yang diatur dalam PP tersebut diantaranya tentang: (1) izin usaha pertambangan (IUP) dan (2) izin usaha pertambangan khusus.

7. Keputusan Menteri Energi dan Sumber Daya Mineral Nomor 1614 Tahun 2004 Tentang Pedoman Pemprosesan Permohonan Kontrak Karya dan Perjanjian Karya Pengusahaan Pertambangan Batubara dalam rangka Penanaman Modal Asing. Keputusan Menteri ESDM No. 1614 Tahun 2004 ini merupakan petunjuk teknis dalam pelaksanaan Kontrak Karya dan PKP2B di Indonesia, terdiri dari VI bab dan 33 Pasal.

Penanaman modal asing (PMA) terutama di negara-negara yang sedang berkembang termasuk di Indonesia adalah diperuntukkan bagi pengembangan usaha dan menggali potensi menjadi kekuatan ekonomi riil dengan memanfaatkan potensi-potensi modal, skill atau managerial dan teknologi yang dibawa serta para investor asing untuk akselerasi pembangunan ekonomi negara berkembang sepanjang tidak mengakibatkan ketergantungan yang terus-menerus serta tidak merugikan kepentingan nasional. (Rakhmawati, 2003: 8). Setiap orang atau badan hukum asing dan/atau campuran antara badan hukum asing dengan badan hukum Indonesia yang ingin menanamkan modalnya di bidang pertambangan umum 
harus memenuhi prosedur dan syarat-syarat yang telah ditentukan oleh Pemerintah Indonesia.

Penanaman modal asing di bidang pertambangan umum dilaksanakan dalam bentuk kontrak karya. Oleh sebab itu, setiap perusahaan pertambangan yang ingin memperoleh Kontrak Karya, harus mengajukan permohonan kontrak karya dalam rangka penanaman modal asing (PMA) maupun penanaman modal dalam negeri (PMDN) kepada pejabat yang berwenang. Pejabat berwenang menanda tangani Kontrak Karya adalah Bupati/Walikota, Gubernur dan Menteri Energi Sumber daya Mineral. Penandatanganan Kontrak Karya oleh pejabat ini disesuaikan dengan kewenangannya. Apabila wilayah kontrak yang dimohon berada dalam wilayah kabupaten, pejabat yang berwenang menandatangani Kontrak Karya adalah Bupati/Walikota, jika di dua kota/kabupaten yang berbeda maka yang menandatangani adalah Gubernur. Sementara itu, apabila wilayah pertambangan yang dimohon berada di dua wilayah provinsi yang berbeda, yang berwenang menandatanganinya adalah Menteri Energi Sumber Daya Mineral dengan pemohon.

Prosedur permohonan Kontrak Karya pada wilayah kewenangan Buapti/Walikota, disajikan sebagai berikut:

1. Permohonan diajukan kepada Bupati/Walikota di dalam Keputusan Menteri Energi dan Sumber Daya Mineral No. 1453 K/29/MEM/2000 tentang Pedoman Teknis Penyelenggaraan Tugas Pemerintahan di Bidang Pertambangan Umum, telah ditentukan contoh format permohonan Kontrak Karya yang diajukan kepada Bupati/Walikota;

2. Bupati/Walikota memberikan persetujuan prinsip;

3. Bupati/Walikota melakukan konsultasi kepada DPRD kabupaten/kota (standar kontrak disusun oleh pemerintah);

4. Permohonan rekomendasi ke dinas Penanaman Modal;

5. Dinas Penanaman Modal memberikan rekomendasi;

6. Bupati/walikota bersama pemohon menandatangani kontrak.

Kontrak yang ditandatangani tersebut ditembuskan kepada provinsi dan departemen Energi dan Sumber Daya Mineral. Prosedur permohonan Kontrak Karya pada wilayah Gubernur disajikan sebagai berikut:

1. Permohonan diajukan ke Gubernur, format permohonan untuk mengajukan permohonan Kontrak Karya kepada Gubernur adalah sama dengan format permohonan yang diajukan kepada Bupati/Walikota;

2. Gubernur memberikan persetujuan;

3. Gubernur melakukan konsultasi kepada DPRD provinsi (standar kontrak disusun oleh pemerintah);

4. Permohonan rekomendasi ke BMKMD;

5. DPRD provinsi memebeikan rekomendasi; 
6. BKPMD memberikan rekomendasi;

7. Gubernur bersama pemohon menandatangani kontrak;

8. Kontrak ditembuskan kepada Kabupaten/Kota dan Departemen Energi dan Sumber Daya Mineral.

Dalam konteks ini, meskipun Bupati/Walikota dan Gubernur diberikan kewenangan untuk menandatangani kontrak karya, namun substansi kontrak karya disiapkan oleh pemerintah pusat. Ini menunjukan bahwa pemerintah pusat belum sepenuhnya menyerahkan kewenangan itu kepada Pemerintah Daerah. Di samping itu, Pemerintah Daerah belum mempunyai pengalaman yang cukup dalam penyusunan substansi Kontrak Karya. Apabila substansi Kontrak Karya diserahkan kepada Pemerintah Daerah untuk menyusunnya, maka memerlukan waktu yang lama dan biaya yang besar. Sementara investor menginginkan supaya Kontrak Karya dapat ditandatangani dalam waktu yang relatif cepat. Karena ditandatanganinya kontrak itu, investor dapat melaksanakan kegiatan eksplorasi terhadap sumber daya alam tambang. Secara garis besar dapat dikatakan bahwa, pengelola dan pengendalian tetap harus dikuasai Negara sebagai organisasi tertinggi yang memiliki kewenangan dalam bidang perizinan, dalam hal ini hak penguasaan negara merupakan instrument sedangkan "sebesar-besarnya kemakmuran rakyat" adalah tujuan akhir pengelolaan kekayaan alam. (Sutedi, 2011: 25).

\section{Kesimpulan}

Berdasarkan uraian artikel diatas, penulis menyimpulkan dalam beberapa hal, pertama, Indonesia merupakan Negara yang memiliki kekayaan alam melimpah, salah satunya dalam bidang pertambangan. Dalam hal eksplorasi dan ekploitasi pertambangan, Indonesia masih menerapkan kerjasama dengan pihak asing. Ketentuan ini diatur dalam undang-undang penanaman modal. Kerja sama ini kemudian dikenal dengan kontrak karya. Kedua, Kontrak Karya lahir bermula ketika pemerintah Indonesia pada bulan April 1967 menandatangani kontrak pertambangan pertama dengan Freeport McMoran dari Amerika Serikat. Kontrak tersebut dikenal dengan sebutan Kontrak Karya generasi I.

Dalam kontrak tersebut pada prinsipnya Hak Penguasaan Negara berisi wewenang untuk mengatur, mengurus dan mengawasi pengelolaan atau pengusahaan pertambangan, serta berisi kewajiban untuk mempergunakan sebesar-besarnya untuk kemakmuran rakyat. Penguasaan oleh negara diselenggarakan oleh pemerintah. Namun, dalam praktinya, pengelolaannya justru dikendalikan oleh asing sementara pemerintah pusat seperti tidak berdaya. 


\section{Daftar Pustaka}

Abrar, S. (2004). Hukum Pertambangan. Yogyakarta: UII Press.

Awaliyah, S. (2016). Kontrak karya dan perjanjian karya pengusahaan pertambangan batubara (KK/PKP2B). Jurnal Ilmiah Pendidikan Pancasila dan Kewarganegaraan, 27(2).

Harsono, B. (1994). Hukum Agraria Indonesia: Sejarah Pembentukan Undang-Undang Pokok Agraria, Isi dan Pelaksanaannya. Jakarta: Djambatan.

Ilmar, A. (2004). Hukum Penanaman Modal di Indonesia. Jakarta: Kencana.

Rakhmawati, N. R. (2003). Hukum Penanaman Modal di Indonesia Dalam Menghadapi Era Global. Malang: Bayumedia Publising.

Salim, H. S. (2005). Hukum Pertambangan di Indonesia. Jakarta: RajaGrafindo Persada.

Salim HS. (2003). Perkembangan Hukum Kontrak Innominaat di Indonesia. Jakarta: Sinar Grafika.

Sangaji, A. (2002). Buruk Inco, rakyat digusur: ekonomi politik pertambangan Indonesia. Jakarta: Pustaka Sinar Harapan.

Soelistijo, U. W. (2011). Dinamika Penanaman Modal Asing (PMA) Bidang Pertambangan Umum di Indonesia. Mimbar, Jurnal Sosial dan Pembangunan, 27(1), 79-86.

Subekti, R. (1995). Aneka Perjanjian. Bandung: Citra Aditya Bakti.

Sudrajat, N. (2013). Teori dan Praktik Pertambangan Indonesia. Yogyakarta: Pustaka Yustisia.

Sutedi, A. (2011). Hukum Pertambangan. Jakarta: Sinar Grafika.

Toruan, H. D. L. (2016). Pergeseran paradigma hukum investasi pertambangan. Jurnal rechts vinding, 4(2). 
Problematika Kontrak Karya Dalam Hukum Perjanjian Di

Indonesia

Trihastuti, N. (2013). Hukum Kontrak Karya: Pola Kerjasama Pengusahaan Pertambangan Indonesia. Malang: Setara Press.

Wiriosudarmo, R. (1995). Kebijaksanaan Mineral dalam menghadapi Era Pasar Bebas. Bandung: Perhapi. 